\title{
Research Performance of Sri Sivasubramaniya Nadar College of Engineering, Chennai, Tamil Nadu, India
}

\author{
$\mathrm{J}_{\text {Arumugam }}{ }^{1}$ \\ \{jacs1986tv1@gmail.com $\left.{ }^{1}\right\}$ \\ Librarian, PSG College of Technology, Coimbatore, Tamil Nadu, India ${ }^{1}$
}

\begin{abstract}
This paper investigated about the research performance of Sri Siva Subramaniya Nadar College of Engineering is the one of the prominent technical institution in Chennai, Tamil Nadu, India. The objectives of the study are to analyze the various scientific research parameters of Sri Siva Subramaniya Nadar College of Engineering to plan for the future course of actions. This study analyzes and visualizes scholarly publications of Sri Siva Subramaniya Nadar College of Engineering using SCOPUS data from the period 2003. There are various qualitative and quantitative methods to measure research performance. This study adopted a number of Publications based on author, institution, country, and year, type of documents, subject area and number of citations. Relative Growth rate, Doubling Time, Coauthor Activity Index and analyzed by VOS Viewer and R Tool. Sri Siva Subramaniya Nadar College of Engineering leads in research productivity compared to other engineering colleges in Tamil Nadu during recent year. It also collaborated with Anna University, Chennai. United States is the predominant collaborative country for their research work. Moreover Department of Science and Technology has predominantly sponsored for the research activities of this institution. This analysis results indicate that publishing in top-ranked journals would improve the chance of getting more citations. The study considered only publications that are indexed in SCOPUS. It covered a limited set of sources as per the SCOPUS editorial policy. Most of the covered sources are journals and conference proceedings. Sri Siva Subramaniya Nadar College of Engineering is a technology based institution, and the majority of its academic departments fall in Engineering and Technology domains.
\end{abstract}

Keywords: Scientometrics, Research impact, Relative Growth Rate, VOS Viewer, Research performance, SSN College of Engineering, Chennai.

\section{Introduction}

Sri Siva Subramaniya Nadar College of Engineering, Chennai is one of the most prominent technical institutions in Tamil Nadu. Research productivity and citations are also significant factors in the ranking of institutions by various agencies. Hence, a study to analyze various aspects of Sri Sivasubramaniya Nadar College of Engineering research works and compare it with the peer institutions in the country is very significant to help the institution in formulating strategies for research planning and funding. This study has performed the scientometric analysis and visualization of the scholarly publications of Sri Siva Subramaniya Nadar College of Engineering, Chennai using SCOPUS, a citation database by Elsevier. The study used VOS Viewer for analyzing and visualizing citation networks. The findings of this study are expected to help Sri Siva Subramaniya Nadar College of Engineering have a thorough understanding of 
the research impact of its publications and help to frame research policies to formulate strategies for increasing the visibility and citation impact of institution.

Vasistha (2011) has reported the research publication output of PEC University of Technology, Chandigarh and found that there is a increase in the output by $131.85 \%$ between 1996 and 2009. Savanur and Konnur (2012) have studied the research output of Bangalore University in the period of 1970 to 2010 and found that the growth rate of publications was highest during 1996 and 2000 and gradual decrease found after 2001. Maharana and Sethi have studied the publication output of Sambalpur University during 2007-2011 and analysed the various scientific parameters of the institution. Arumugam et.al (2019) analysed the Scholarly Research Output of Indian Institute of Management (IIMs) in India and found that significant contribution from the faculty of IIM Ahmedabad with $85.3 \%$ publications.

\section{Aim and Objectives of the Study}

The primary aim of this study was to analyze Sri Sivasubramaniya Nadar College of Engineering research output patterns and analyze area of growth to help the institution to formulate research planning to meet out the future requirements

The following are the objectives of the study

* To find out the chronological growth of research publication output

* To explore the various types of publication.

* To identify the most productive authors and authorship pattern.

* To find out major research areas of the university in terms of published works.

* To find out the impact of international collaborations and source of publications on received citations.

\section{Methodology}

Data on publication output of SSN College of Engineering were collected from the Scopus database for all the years from 2003 to 2020. Scopus, a product of Elsevier is covers nearly 30,000 titles from over 5,000 publishers and is the largest abstract and citation database of peerreviewed literature covering science, technology, medicine, social sciences, arts and humanities. It also provides author profiles which cover affiliations, number of publications and their bibliographic data, references, and details on the number of citations each published document has received. It has a facility to calculate h-index of authors and institutions. The query: AFID ( " Sri Sivasubramaniya Nadar College of Engineering, Kalavakkam" 60079728) AND ( LIMIT-TO ( PUBYEAR , 2020 ) OR LIMITTO ( PUBYEAR , 2003 ) ) was used to retrieve details of research publications emanating from SSN College of Engineering. The study adopted VOS Viewer, a domain visualization tool to process data and make visualization graphs using SCOPUS data. VOS Viewer supports various bibliometric and citation analysis matrices and visualizes them using different network algorithms. 


\section{Limitations Of The Study}

The study considered only publications that are indexed in SCOPUS. It covered a limited set of sources as per the SCOPUS editorial policy. Most of the covered sources are journals and conference proceedings. Books' data coverage in Citation Index is comparatively low, and the majority of the academic departments fall in engineering and technology domains.

\section{Analysis}

\section{Type of Resources}

The below figure clearly shows that there are good number of articles published in subscribes resources compared to open access platforms which clearly indicated, there is a lack of awareness among the faculty about open access publishing in the technical institutions.

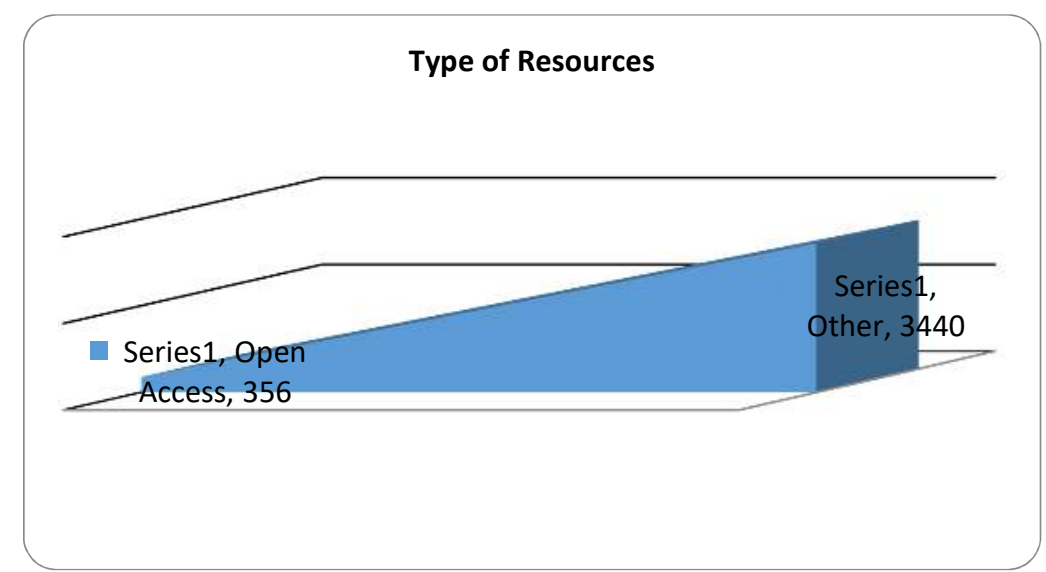

Figure 1. Type of Publishing Resources

\section{Chronological Growth of Publications}

Table 1 shows significant increase in publication started from 2003 with 6 publications and 2019 is the most productive year with 595 (15.67\%) publications followed by 2018 and 2017 with $524(13.8 \%)$ and $421(11.09 \%)$ publications respectively. The publication output of last ten years, i.e. from 2011 to 2020 contributes 3394 (89.40\%) publications of the total of 3796 in 18 years (2003 to 2020).

\begin{tabular}{|l|l|l|l|}
\hline \multirow{2}{*}{ Year Range } & \multicolumn{2}{|l|}{ Year } & \multirow{2}{*}{ Total Publication } \\
\cline { 2 - 3 } & No of Publication & Percentage & \multirow{2}{*}{3796} \\
\hline $2003-2010$ & 402 & 10.59009 & \\
\hline $2011-2020$ & 3394 & 89.40991 & \\
\hline
\end{tabular}

Table 1. Year-wise Output of Publications 


\section{Relative Growth Rate [R(a)]}

The relative growth rate is the increase in the number of publications per unit of time i.e. one year. The mean relative growth rate $\mathrm{R}(1-2)$ over a specified period of interval can be calculated from the following equation suggested by Mahapatra

where,

$\mathrm{R}(1-2)=$ Mean relative growth rate over a specific period of interval;

$\mathrm{W} 1=$ Log W1 (Natural log of initial number of publications at beginning);

$\mathrm{W} 2=\mathrm{Log}$ W2 (Natural log of initial number of publications at end);

$\mathrm{T} 2-\mathrm{T} 1=$ Unit difference between the beginning time and end time.

Therefore, $R(a)=$ Relative growth rate per unit of publications per unit of time (year).

The Relative Growth Rate $\mathrm{R}(\mathrm{a})$ and Doubling Time $\mathrm{D}(\mathrm{t})$ of publication output of SSN College of Engineering are derived and presented in Table 2 and the results show that till 2008 there was not good number of publications when compare with the last 10 years. The relative growth rate ranges between 1.79 to 0.88 . The mean relative growth rate is 0.46 .

\section{Doubling Time (DT )}

A direct equivalence exists between the relative growth rate and doubling time. The doubling time for publication can be calculated by the following formula suggested by Mahapatra. Therefore, The doubling time for publication output of SSN College of Engineering increased from 2007(1.07) onwards till 2020 to 20.87 in 2020. The doubling time for publications at the aggregate level has been computed as 1.2 years. There is a progressive growth in the number of publications of research output of SSN College of Engineering but its Doubling time is showing a increasing trend, since the rate of increase is high.

\begin{tabular}{|c|c|c|c|c|c|c|}
\hline Year & No. of Records & Cumulative & log W1 & log W2 & RGR & Doubling Time \\
\hline 2003 & 6 & 6 & 0.00 & 1.79 & 1.79 & 0.39 \\
\hline 2004 & 4 & 10 & 1.79 & 2.30 & 0.51 & 1.36 \\
\hline 2005 & 10 & 20 & 2.30 & 3.00 & 0.69 & 1.00 \\
\hline 2006 & 28 & 48 & 3.00 & 3.87 & 0.88 & 0.79 \\
\hline 2007 & 44 & 92 & 3.87 & 4.52 & 0.65 & 1.07 \\
\hline 2008 & 70 & 162 & 4.52 & 5.09 & 0.57 & 1.22 \\
\hline 2009 & 108 & 270 & 5.09 & 5.60 & 0.51 & 1.36 \\
\hline 2010 & 132 & 402 & 5.60 & 6.00 & 0.40 & 1.74 \\
\hline 2011 & 203 & 605 & 6.00 & 6.41 & 0.41 & 1.70 \\
\hline 2012 & 220 & 825 & 6.41 & 6.72 & 0.31 & 2.23 \\
\hline 2013 & 246 & 1071 & 6.72 & 6.98 & 0.26 & 2.66 \\
\hline 2014 & 311 & 1382 & 6.98 & 7.23 & 0.25 & 2.72 \\
\hline 2015 & 396 & 1778 & 7.23 & 7.48 & 0.25 & 2.75 \\
\hline 2016 & 354 & 2132 & 7.48 & 7.66 & 0.18 & 3.82 \\
\hline 2017 & 421 & 2553 & 7.66 & 7.85 & 0.18 & 3.85 \\
\hline
\end{tabular}




\begin{tabular}{|c|c|c|c|c|c|c|}
2018 & 524 & 3077 & 7.85 & 8.03 & 0.19 & 3.71 \\
\hline 2019 & 595 & 3672 & 8.03 & 8.21 & 0.18 & 3.92 \\
\hline 2020 & 124 & 3796 & 8.21 & 8.24 & 0.03 & 20.87 \\
\hline
\end{tabular}

Table 2 Relative Growth Rate and Doubling Time

Annual Growth Rate (AGR)

This is one of the indicators of Annual Growth Rate (AGR) for each year. The formula for AGR is: $\mathbf{A G R}=$ (Ending Value Beginning Value) $/$ Beginning value

The formula for AAGR is: AAGR $=($ Growth Rate in Period A + Growth Rate in Period B + Growth Rate in Period C + ...Growth Rate in Period X) / Number of Periods

\begin{tabular}{|l|c|c|c|c|}
\hline S.No & Year & No of Publications & ARoG & AGR \\
\hline 1. & 2003 & 6 & & \\
\hline 2. & 2004 & 4 & 0.667 & -0.333 \\
\hline 3. & 2005 & 10 & 2.500 & 1.500 \\
\hline 4. & 2006 & 28 & 2.800 & 1.800 \\
\hline 5. & 2007 & 44 & 1.571 & 0.571 \\
\hline 6. & 2008 & 70 & 1.591 & 0.591 \\
\hline 7. & 2009 & 108 & 1.543 & 0.543 \\
\hline 8. & 2010 & 132 & 1.222 & 0.222 \\
\hline 9. & 2011 & 203 & 1.538 & 0.538 \\
\hline 10. & 2012 & 220 & 1.084 & 0.084 \\
\hline 11. & 2013 & 246 & 1.118 & 0.118 \\
\hline 12. & 2014 & 311 & 1.264 & 0.264 \\
\hline 13. & 2015 & 396 & 1.273 & 0.273 \\
\hline 14. & 2016 & 354 & 0.894 & -0.106 \\
\hline 15. & 2017 & 421 & 1.189 & 0.189 \\
\hline 16. & 2018 & 524 & 1.245 & 0.245 \\
\hline 17. & 2019 & 595 & 1.135 & 0.135 \\
\hline 18. & 2020 & 124 & 0.208 & -0.792 \\
\hline
\end{tabular}

Table 3 Annual Ratio of Growth and Annual Growth Rate

The AGR is the highest in 2006 (1.800) followed by 2005(1.500) and 2008(0.591). The AGR is the lowest in $2012(0.084)$. As far as negative growth rate is concerned, the year 2016 has the AGR -0.106 of followed by -0.333 in 2004 . There is a fluctuation in the AGR of SSN College of Engineering research output during the study period. 


\section{Document Type Distribution}

Tables 4 shows that the faculty of SSN College of Engineering mostly published their research findings in the form of journal articles (2192 with 57.74\%) as the preferred channel for their publications. They have also presented their papers in $1437(37.85 \%)$ conferences. They have published $39(1.03 \%)$ review papers as well. Other types like book chapter $97(2.55 \%)$, books ( 4 of $0.104 \%$ ) are also the source of publications. Remaining forms like short survey, editorial and so on.

\begin{tabular}{|c|c|c|c|}
\hline S.No & Document Type & No of Publications & Percentage (\%) \\
\hline 1 & Article & 2192 & 57.74 \\
\hline 2 & Conference Paper & 1437 & 37.85 \\
\hline 3 & Book Chapter & 97 & 2.55 \\
\hline 4 & Review & 39 & 1.02 \\
\hline 5 & Editorial & 8 & 0.21 \\
\hline 6 & Erratum & 6 & 0.15 \\
\hline 7 & Book & 4 & 0.10 \\
\hline 8 & Letter & 3 & 0.07 \\
\hline 9 & Data Paper & 2 & 0.05 \\
\hline 10 & Note & 2 & 0.05 \\
\hline 11 & Short Survey & 1 & 0.02 \\
\hline 12 & Undefined & 5 & 0.13 \\
\hline
\end{tabular}

Table 4. Type of Documents

Predominant Authors of the Institution

Table 5 reveals that Ramasamy, $\mathrm{P}$ is the most productive author with $417(10.98 \%)$ publications followed by Radha, S..with 134 (3.53\%) publications. Below table represents the top 20 ranking of authors based on the publications.

\begin{tabular}{|l|l|l|l|}
\hline S.No & Author & No of Publications & Percentage (\%) \\
\hline 1 & Ramasamy, P. & 417 & 10.98 \\
\hline 2 & Radha, S. & 134 & 3.53 \\
\hline 3 & Senthil Kumar, P. & 101 & 2.66 \\
\hline 4 & Amutha, R. & 75 & 1.97 \\
\hline 5 & Ramaprabha, R. & 74 & 1.94 \\
\hline 6 & Rajini, V. & 70 & 1.84 \\
\hline 7 & Srinivasan, R. & 65 & 1.71 \\
\hline 8 & Sreeja, B.S. & 62 & 1.63 \\
\hline 9 & Kumar, P.S. & 60 & 1.58 \\
\hline 10 & Vishvaksenan, K.S. & 59 & 1.55 \\
\hline 11 & Kamaraj, V. & 55 & 1.44 \\
\hline 12 & Rajesh, N.P. & 53 & 1.39 \\
\hline 13 & Pandian, M.S. & 52 & 1.36 \\
\hline
\end{tabular}

Table 5: Ranking of Authors 


\begin{tabular}{|l|l|l|l|}
\hline 14 & Vijayalakshmi, P. & 52 & 1.36 \\
\hline 15 & Muthu, R. & 50 & 1.31 \\
\hline 16 & Nagarajan, T. & 50 & 1.31 \\
\hline 17 & Rajesh, P. & 50 & 1.31 \\
\hline 18 & Senthil Pandian, M. & 49 & 1.29 \\
\hline 19 & Seyezhai, R. & 48 & 1.26 \\
\hline 20 & Kanagasabai, M. & 46 & 1.21 \\
\hline
\end{tabular}

\section{Authorship Pattern}

Table 6 shows that 3678 papers are collaborative publications. Two author papers (1260 with CAI 239.12) and followed by more than two author's collaborative papers (2418 with CAI 85.03). 118 papers (CAI 27.75) were contributed by single authors.

\begin{tabular}{|l|l|l|l|l|l|l|l|}
\hline \multicolumn{2}{|l}{ Co-Authorship Index } \\
\hline Year & $\begin{array}{l}\text { Single } \\
\text { Author }\end{array}$ & CAI & $\begin{array}{l}\text { Two } \\
\text { Authors }\end{array}$ & CAI & $\begin{array}{l}\text { More than } \\
\text { Two Authors }\end{array}$ & CAI & Total \\
\hline 2003 & 0 & 0.00 & 3 & 360.20 & 3 & 66.74 & 6 \\
\hline 2004 & 1 & 223.15 & 0 & 0.00 & 3 & 100.11 & 4 \\
\hline 2005 & 1 & 89.26 & 2 & 144.08 & 7 & 93.44 & 10 \\
\hline 2006 & 0 & 0.00 & 6 & 154.37 & 22 & 104.88 & 28 \\
\hline 2007 & 3 & 60.86 & 9 & 147.35 & 32 & 97.08 & 44 \\
\hline 2008 & 4 & 51.01 & 26 & 267.57 & 40 & 76.28 & 70 \\
\hline 2009 & 5 & 41.32 & 42 & 280.15 & 61 & 75.39 & 108 \\
\hline 2010 & 9 & 60.86 & 51 & 278.33 & 72 & 72.81 & 132 \\
\hline 2011 & 5 & 21.99 & 89 & 315.84 & 109 & 71.67 & 203 \\
\hline 2012 & 11 & 44.63 & 85 & 278.33 & 124 & 75.24 & 220 \\
\hline 2013 & 5 & 18.14 & 99 & 289.91 & 142 & 77.05 & 246 \\
\hline 2014 & 12 & 34.44 & 110 & 254.80 & 189 & 81.12 & 311 \\
\hline 2015 & 12 & 27.05 & 154 & 280.15 & 230 & 77.53 & 396 \\
\hline 2016 & 17 & 42.87 & 117 & 238.10 & 220 & 82.96 & 354 \\
\hline 2017 & 11 & 23.32 & 130 & 222.45 & 280 & 88.78 & 421 \\
\hline 2018 & 9 & 15.33 & 139 & 191.10 & 376 & 95.78 & 524 \\
\hline 2019 & 12 & 18.00 & 162 & 196.14 & 421 & 94.45 & 595 \\
\hline 2020 & 1 & 7.20 & 36 & 209.15 & 87 & 93.65 & 124 \\
\hline Total & 118 & 27.75 & 1260 & 239.12 & 2418 & 85.03 & 3796 \\
\hline
\end{tabular}

Table 6. Authorship Pattern 
Collaborative co-efficient is used to measure the extent of collaboration. The measure of the degree of collaboration in a discipline lies between 0 and 1 according to the formula of Subramanyam

$\mathrm{C}=\mathrm{Nm} / \mathrm{Nm}+\mathrm{Ns}$.

$\mathrm{C}$ : Degree of Collaboration

$\mathrm{Nm}$ : Number of multi-authored publications

Ns: Number of single authored publications

Hence $\mathrm{C}=0.95$ Hence, it is found that the degree of collaboration of publications of SSN College of Engineering faculty is 0.95 .

\section{Pattern of Co-Authorship}

In order to assess the Pattern of Co-Authorship (CAI), the following formula suggested by Garg and Padhi has been employed.

Nij/Nio CAI = ---------- Noj/No

Where, $\mathrm{Nij}=$ Number of papers having authors in block $\mathrm{i}$

Nio $=$ Total output of block i

Noj $=$ Number of papers having $\mathrm{j}$ authors for all blocks

$\mathrm{N} \infty=$ Total number of papers for all authors and all blocks

Hence $\mathrm{CAI}=27.75$ for single author, 239.12 for two authors, 85.03 for multiple author.

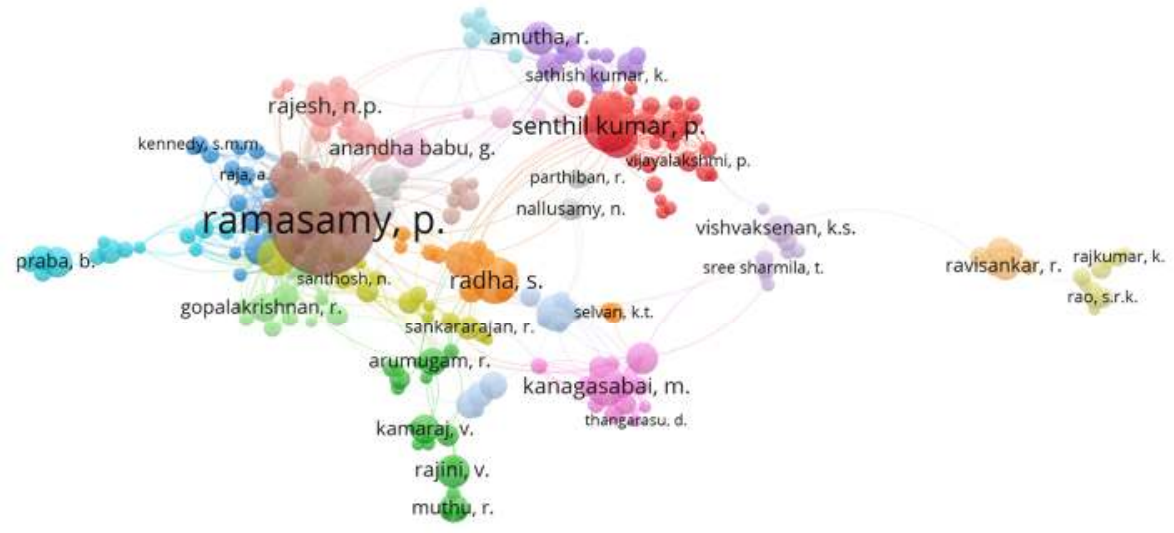

\section{A vosviewer}

\section{Source wise Distribution}

Figure 2. Pattern of Co-Authorship

Table 7 shows that the distribution of journals based on publications on which the papers appeared indicates a high degree of scatter in terms of number of journals. The top 20 journals accounted for less than $20 \%$ of all publications output.

\begin{tabular}{|l|l|l|l|}
\hline S.No & Name of the Source & $\begin{array}{l}\text { No of } \\
\text { Publications }\end{array}$ & Percentage (\%) \\
\hline 1 & Aip Conference Proceedings & 125 & 3.29 \\
\hline 2 & Journal Of Crystal Growth & 93 & 2.44 \\
\hline
\end{tabular}




\begin{tabular}{|c|c|c|c|}
\hline 3 & International Journal Of Applied Engineering Research & 88 & 2.31 \\
\hline 4 & Advances In Intelligent Systems And Computing & 62 & 1.63 \\
\hline 5 & $\begin{array}{l}\text { IEEE Region } 10 \text { Annual International Conference } \\
\text { Proceedings TENCON }\end{array}$ & 42 & 1.10 \\
\hline 6 & Desalination And Water Treatment & 40 & 1.05 \\
\hline 7 & European Journal Of Scientific Research & 36 & 0.94 \\
\hline 8 & Lecture Notes In Mechanical Engineering & 35 & 0.92 \\
\hline 9 & $\begin{array}{lllll}\text { Spectrochimica Acta Part A } & \text { Molecular } & \text { And } \\
\text { Biomolecular Spectroscopy } & & & \\
\end{array}$ & 35 & 0.92 \\
\hline 10 & Materials Today Proceedings & 32 & 0.84 \\
\hline 11 & Arpn Journal Of Engineering And Applied Sciences & 31 & 0.81 \\
\hline 12 & Advanced Materials Research & 30 & 0.79 \\
\hline 13 & Communications In Computer And Information Science & 30 & 0.79 \\
\hline 14 & $\begin{array}{l}\text { International Conference On Communication And } \\
\text { Signal Processing Iccsp } 2014 \text { Proceedings }\end{array}$ & 29 & 0.76 \\
\hline 15 & Multimedia Tools And Applications & 27 & 0.71 \\
\hline 16 & Materials Letters & 26 & 0.68 \\
\hline 17 & Optik & 26 & 0.68 \\
\hline 18 & Cluster Computing & 24 & 0.63 \\
\hline 19 & $\begin{array}{l}\text { International Journal of Recent Technology And } \\
\text { Engineering }\end{array}$ & 23 & 0.60 \\
\hline 20 & Journal Of Materials Science Materials In Electronics & 23 & 0.60 \\
\hline
\end{tabular}

Table 7. Ranking of Journals based on Publications

Collaborative Country

Figure 3 shows that the faculty of SSN College of Engineering collaborated most with researchers of India (3793) followed by United States 83 publications. 


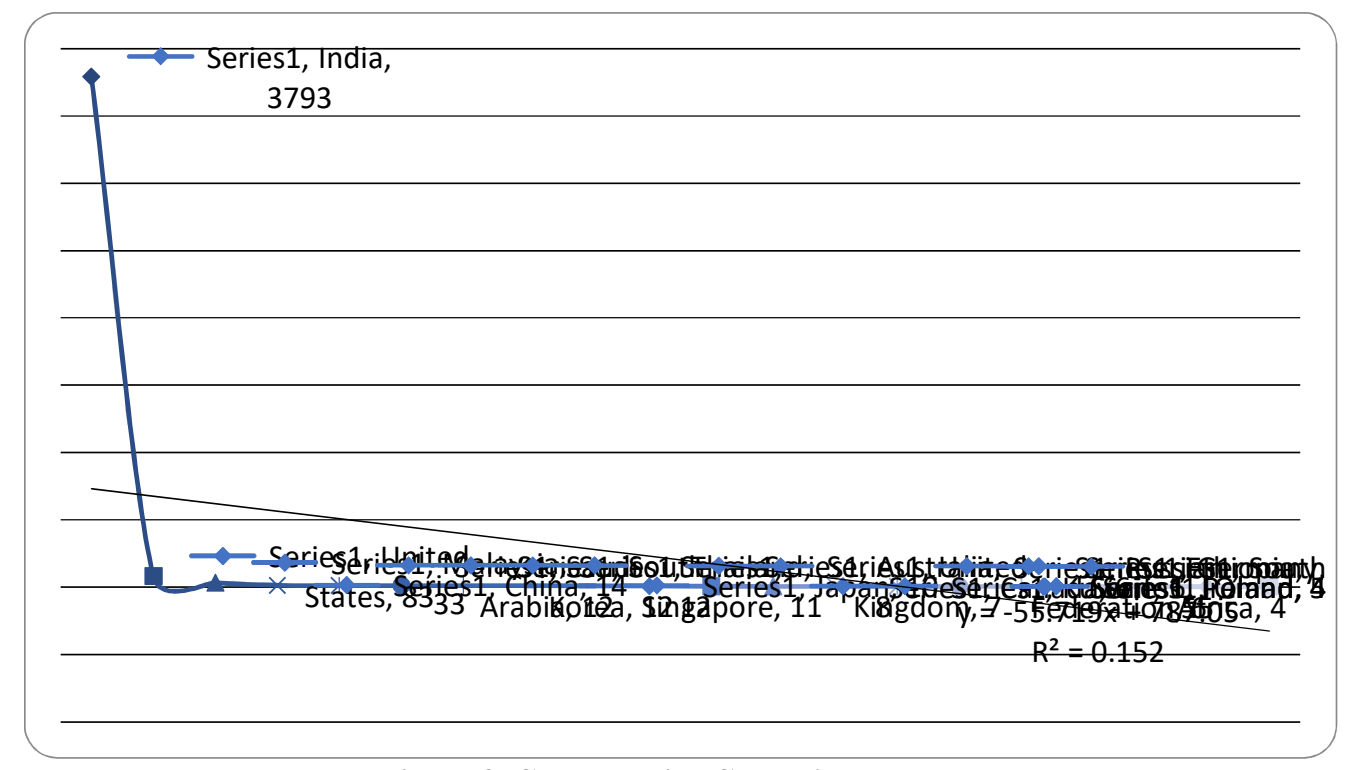

Figure 3. Collaborative Countries

\section{Collaborative Institutions}

Table 8 shows that researchers from 20 institutions collaborated with the faculty of SSN College Of Engineering for more than 20 publications. Among them, Anna University stands first with 537 publications.

\begin{tabular}{|l|l|l|l|}
\hline S.No & Collaborative Institutions & No of Publication & Percentage (\%) \\
\hline 1 & Anna University & 537 & 14.14 \\
\hline 2 & Vellore Institute of Technology, Chennai and & 100 & 2.63 \\
\hline 3 & $\begin{array}{l}\text { Sathyabama Institute of Science } \\
\text { Technology }\end{array}$ & 71 & 1.87 \\
\hline 4 & Vellore Institute of Technology, Vellore & 70 & 1.84 \\
\hline 5 & College of Engineering, Guindy & 69 & 1.81 \\
\hline 6 & Rajalakshmi Engineering College & 68 & 1.79 \\
\hline 7 & Indian Institute of Technology Madras & 65 & 1.71 \\
\hline 8 & National Physical Laboratory India & 56 & 1.47 \\
\hline 9 & Indira Gandhi Centre for Atomic Research & 50 & 1.31 \\
\hline 10 & $\begin{array}{l}\text { Sri Venkateswara College of Engineering, } \\
\text { Sriperumbudur }\end{array}$ & 44 & 1.15 \\
\hline 11 & St. Joseph's College of Engineering & 41 & 1.08 \\
\hline 12 & $\begin{array}{l}\text { SRM Institute of Science and Technology, } \\
\text { Ramapuram Campus }\end{array}$ & 36 & 0.94 \\
\hline 13 & Sri Sai Ram Engineering College, Chennai & 34 & 0.89 \\
\hline 14 & SRM Institute of Science and Technology & 31 & 0.81 \\
\hline
\end{tabular}




\begin{tabular}{|l|l|l|l|}
\hline 15 & KCG College of Technology & 24 & 0.63 \\
\hline 16 & SASTRA Deemed University & 23 & 0.60 \\
\hline 17 & Alagappa College of Technology & 22 & 0.57 \\
\hline 18 & Anand Institute of Higher Technology & 21 & 0.55 \\
\hline 19 & Madras Institute of Technology & 20 & 0.52 \\
\hline 20 & Tagore Engineering College & 20 & 0.52 \\
\hline
\end{tabular}

Table 8. Ranking of Collaborative Institutions

\section{Subject wise Distribution}

Table 9 shows that 1930 papers were published in the broad area of 'Engineering' followed by Computer Science (1478) and Physics and Astronomy (834).

\begin{tabular}{|c|c|c|c|}
\hline S.No & Subject Category & No. of Publications & Percentage (\%) \\
\hline 1 & Engineering & 1930 & 50.84 \\
\hline 2 & Computer Science & 1478 & 38.93 \\
\hline 3 & Physics and Astronomy & 834 & 21.97 \\
\hline 4 & Materials Science & 782 & 20.60 \\
\hline 5 & Mathematics & 396 & 10.43 \\
\hline 6 & Chemistry & 395 & 10.40 \\
\hline 7 & Chemical Engineering & 261 & 6.87 \\
\hline 8 & Energy & 261 & 6.87 \\
\hline 9 & Environmental Science & 218 & 5.74 \\
\hline 10 & Biochemistry, Genetics and Molecular Biology & 125 & 3.29 \\
\hline 11 & Medicine & 117 & 3.08 \\
\hline 12 & Earth and Planetary Sciences & 80 & 2.10 \\
\hline 13 & Business, Management and Accounting & 72 & 1.89 \\
\hline 14 & Agricultural and Biological Sciences & 70 & 1.84 \\
\hline 15 & Pharmacology, Toxicology and Pharmaceutics & 63 & 1.65 \\
\hline 16 & Multidisciplinary & 58 & 1.52 \\
\hline 17 & Decision Sciences & 54 & 1.42 \\
\hline 18 & Social Sciences & 48 & 1.26 \\
\hline 19 & Immunology and Microbiology & 19 & 0.50 \\
\hline 20 & Neuroscience & 14 & 0.36 \\
\hline 21 & Health Professions & 12 & 0.31 \\
\hline 22 & Arts and Humanities & 10 & 0.26 \\
\hline 23 & Psychology & 5 & 0.13 \\
\hline 24 & Economics, Econometrics and Finance & 4 & 0.10 \\
\hline 25 & Dentistry & 1 & 0.02 \\
\hline 26 & Nursing & 1 & 0.02 \\
\hline
\end{tabular}

Table 9. Broad Areas of Publication 


\section{Keyword Distribution}

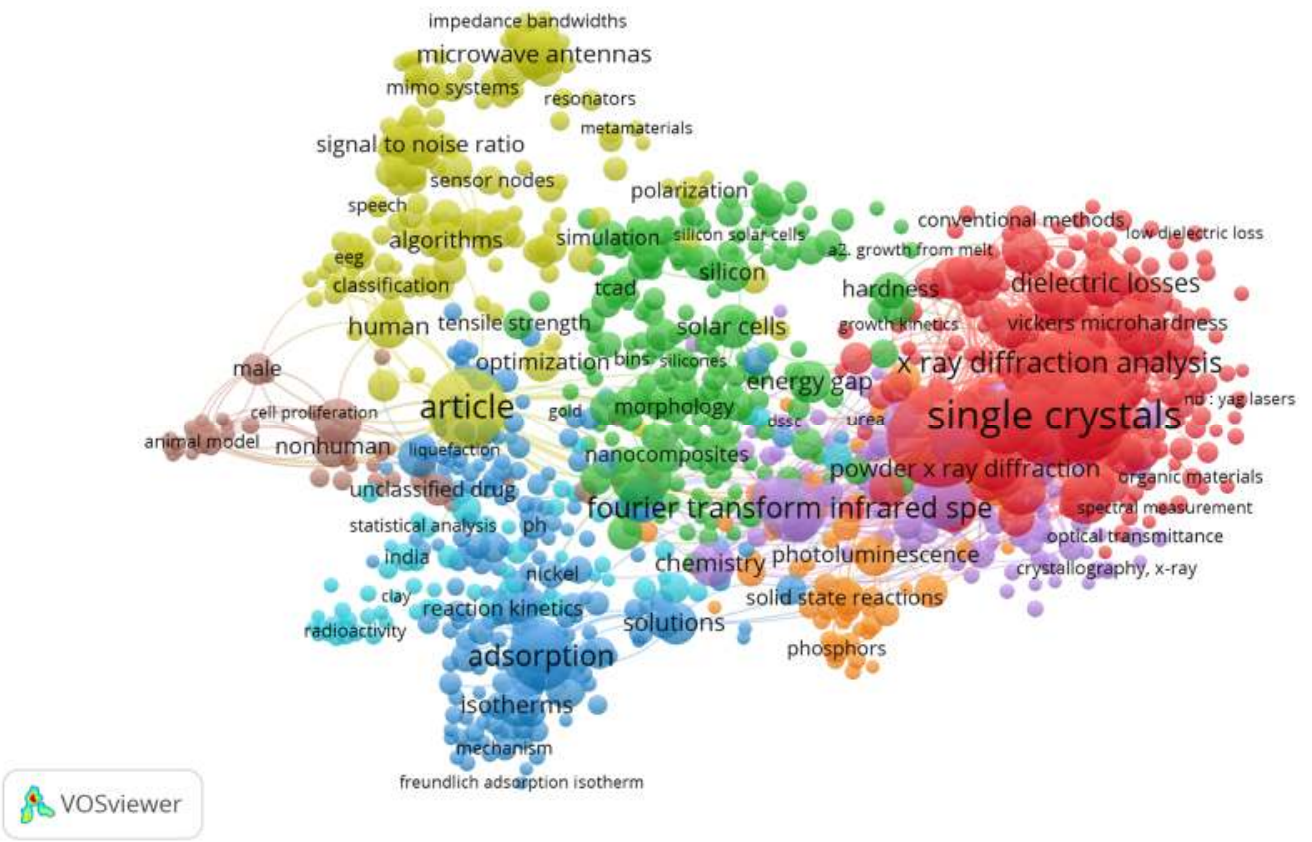

Figure 4: Distribution of Keywords

Figure 4 shows the most predominant keyword used by the faculty of the institution. It also identifies proximity of the relevance keywords used in the publications.

Top Cited Papers

Table 10 shows that top 20 cited papers based on the citations received from the overall period of the study. It is evident that 2338 papers have received below 100 citations and 18 papers have received more than 100 citations. 1440 papers have not received single citations.

\begin{tabular}{|c|c|c|c|c|c|}
\hline S.No & Authors & Title & Year & Source Title & Citation \\
\hline 1 & $\begin{array}{lr}\text { Senthil Kumar } & \text { P., } \\
\text { Ramalingam } & \text { S., } \\
\text { Senthamarai } & \text { C., } \\
\text { Niranjanaa } & \text { M., } \\
\text { Vijayalakshmi } & \text { P., } \\
\text { Sivanesan S. } & \end{array}$ & $\begin{array}{l}\text { Adsorption of dye from } \\
\text { aqueous solution by cashew } \\
\text { nut shell: Studies on } \\
\text { equilibrium } \\
\text { kinetics isotherm, } \\
\text { thermodynamics } \\
\text { interactions }\end{array}$ & 2010 & Desalination & 460 \\
\hline 2 & $\begin{array}{l}\text { Carolin C.F., Kumar } \\
\text { P.S., Saravanan A., } \\
\text { Joshibar G.J., } \\
\text { Naushad M. }\end{array}$ & $\begin{array}{l}\text { Efficient techniques for the } \\
\text { removal of toxic heavy } \\
\text { metals from aquatic } \\
\text { environment: A review }\end{array}$ & 2017 & $\begin{array}{l}\text { Journal of } \\
\text { Environmental } \\
\text { Chemical } \\
\text { Engineering }\end{array}$ & 270 \\
\hline 3 & $\begin{array}{l}\text { Panchatcharam M., } \\
\text { Miriyala S., Gayathri } \\
\text { V.S., Suguna L. }\end{array}$ & $\begin{array}{l}\text { Curcumin improves wound } \\
\text { healing by modulating } \\
\text { collagen and decreasing } \\
\text { reactive oxygen species }\end{array}$ & 2006 & $\begin{array}{l}\text { Molecular and } \\
\text { Cellular } \\
\text { Biochemistry }\end{array}$ & 210 \\
\hline
\end{tabular}




\begin{tabular}{|c|c|c|c|c|c|}
\hline 4 & $\begin{array}{lr}\text { Ravikumar } & \text { K., } \\
\text { Krishnan } & \text { S., } \\
\text { Ramalingam S., Balu } \\
\text { K. }\end{array}$ & $\begin{array}{l}\text { Optimization of process } \\
\text { variables by the application } \\
\text { of response } r \text { surface } \\
\text { methodology for dye } \\
\text { removal using a novel } \\
\text { adsorbent }\end{array}$ & 2007 & $\begin{array}{l}\text { Dyes and } \\
\text { Pigments }\end{array}$ & 180 \\
\hline 5 & $\begin{array}{lr}\text { Kumar } & \text { P.S., } \\
\text { Ramalingam } & \text { S., } \\
\text { Kirupha } & \text { S.D., } \\
\text { Murugesan } & \text { A., } \\
\text { Vidhyadevi } & \text { T., } \\
\text { Sivanesan S. } & \end{array}$ & $\begin{array}{l}\text { Adsorption behavior of } \\
\text { nickel(II) onto cashew nut } \\
\text { shell: Equilibrium, } \\
\text { thermodynamics, kinetics, } \\
\text { mechanism and process } \\
\text { design }\end{array}$ & 2011 & $\begin{array}{l}\text { Chemical } \\
\text { Engineering } \\
\text { Journal }\end{array}$ & 174 \\
\hline 6 & $\begin{array}{l}\text { Pandiarajan } \quad \text { N., } \\
\text { Muthu R. }\end{array}$ & $\begin{array}{l}\text { Mathematical modeling of } \\
\text { photovoltaic module with } \\
\text { Simulink }\end{array}$ & 2011 & $\begin{array}{l}2011 \quad 1 \text { st } \\
\text { International } \\
\text { Conference on } \\
\text { Electrical } \\
\text { Energy } \\
\text { Systems, } \\
\text { ICEES 2011 }\end{array}$ & 164 \\
\hline 7 & Poornachandra S. & $\begin{array}{l}\text { Wavelet-based denoising } \\
\text { using subband dependent } \\
\text { threshold for ECG signals }\end{array}$ & 2008 & $\begin{array}{l}\text { Digital Signal } \\
\text { Processing: A } \\
\text { Review Journal }\end{array}$ & 164 \\
\hline 8 & $\begin{array}{l}\text { Selvaraj V., Alagar } \\
\text { M., Kumar K.S. }\end{array}$ & $\begin{array}{l}\text { Synthesis and } \\
\text { characterization of metal } \\
\text { nanoparticles-decorated } \\
\text { PPY-CNT composite and } \\
\text { their electrocatalytic } \\
\text { oxidation of formic acid and } \\
\text { formaldehyde for fuel cell } \\
\text { applications }\end{array}$ & 2007 & $\begin{array}{l}\text { Applied } \\
\text { Catalysis B: } \\
\text { Environmental }\end{array}$ & 144 \\
\hline 9 & $\begin{array}{lr}\text { Ravilumar } & \text { K., } \\
\text { Ramalingam } & \text { S., } \\
\text { Krishnan S., Balu K. }\end{array}$ & $\begin{array}{l}\text { Application of response } \\
\text { surface methodology to } \\
\text { optimize the process } \\
\text { variables for Reactive Red } \\
\text { and Acid Brown dye } \\
\text { removal using a novel } \\
\text { adsorbent }\end{array}$ & 2006 & $\begin{array}{l}\text { Dyes and } \\
\text { Pigments }\end{array}$ & 144 \\
\hline 10 & $\begin{array}{l}\text { Subbaraj P., Rengaraj } \\
\text { R., Salivahanan S. }\end{array}$ & $\begin{array}{l}\text { Enhancement of combined } \\
\text { heat and power economic } \\
\text { dispatch using self adaptive } \\
\text { real-coded genetic algorithm }\end{array}$ & 2009 & Applied Energy & 132 \\
\hline
\end{tabular}

Table 10. Top Cited Papers

\section{Funding Sponsors}

Below table represented the top 20 funding agencies for SSN College of Engineering. Table 11 is evident that Department of Science and Technology, Government of Kerala have sponsored for (86) publications followed by Department of Science and Technology, Ministry of Science and Technology, India (45), Science and Engineering Research Board (41) and so on. 


\begin{tabular}{|l|l|l|}
\hline S.No & Funding Sponsor & No of Publications \\
\hline 1 & Department of Science and Technology, Government of Kerala & 86 \\
\hline 2 & $\begin{array}{l}\text { Department of Science and Technology, Ministry of Science and } \\
\text { Technology, India }\end{array}$ & 45 \\
\hline 3 & Science and Engineering Research Board & 41 \\
\hline 4 & SSN Educational and Charitable Trust & 31 \\
\hline 5 & SSN College of Engineering & 28 \\
\hline 6 & Ministry of New and Renewable Energy India & 17 \\
\hline 7 & All India Council for Technical Education & 15 \\
\hline 8 & Bangladesh Council of Scientific and Industrial Research & 14 \\
\hline 9 & Defence Research and Development Organisation & 12 \\
\hline 10 & Board of Research in Nuclear Sciences & 10 \\
\hline 11 & University Grants Commission & 10 \\
\hline 12 & Department of Atomic Energy, Government of India & 9 \\
\hline 13 & Singapore Eye Research Institute & 5 \\
\hline 14 & VIT University & 5 \\
\hline 15 & $\begin{array}{l}\text { Department of Science and Technology, Ministry of Science and } \\
\text { Technology }\end{array}$ & 4 \\
\hline 16 & National Natural Science Foundation of China & 4 \\
\hline 17 & Universiti Malaya & 4 \\
\hline 18 & University Grants Committee & 3 \\
\hline 19 & CouncilÂA of Scientific and Industrial Research, India & \\
\hline 20 & Department of Science and Technology, Government of West Bengal & \\
\hline & & \\
\hline 1 & 4 \\
\hline
\end{tabular}

Table 11 Predominant Funding Sponsors

\section{Findings}

3796 papers were published by the faculty of SSN College of Engineering in the span of 24 years from 2003 to 2020.

* Journals are the most preferred channels followed by conference proceedings.

* The relative growth rate ranges between 1.79 to 0.88 .

* The paper entitled 'Adsorption of dye from aqueous solution by cashew nut shell: Studies on equilibrium isotherm, kinetics and thermodynamics of interactions' by Senthil Kumar P., Ramalingam S., Senthamarai C., Niranjanaa M., Vijayalakshmi P., Sivanesan S. in the 'Journal of Desalination' in 2010 is the most cited paper of SSN College of Engineering and has received 460 citations as of now;

* 18 papers have received more than 100 citations and 2338 papers have received 01 to 99 citations. 1440 papers have not received single citation. 


\section{Conclusion}

Nowadays reputation of every institution is measured based on the research output and innovation. This qualitative research work is essential to the technical institution in order to identify the areas of research need to be improved and the current position of technical advancement along with the competitive institutions in the future course of action. This qualitative work brings out the scientific productivity of the institution with respect to various parameters and to promote the weaker section of the institution. This study covers only the data existed in the Scopus database where as other citation databases for the scientific productivity can also be explored for the other quality measures. Moreover It's a prime duty of the Library Science community to explore the scientometric research for every institution and enlighten with the upcoming research areas.

\section{References}

[1] Bharvi, D., Garg, K.C. \& Bali, A. (2003). Scientometrics of the international journal Scientometrics. Scientometrics, 56(1), 81-93. Retrieved from: https://doi.org/10.1023/A:1021950607895

[2] Garg, K. (2002). Scientometrics of laser research in India and China. Scientometrics, 55(1), 71-85. Retrieved from: https://doi.org/10.1023/A:1016050920365

[3] Hood, W., \& Wilson, C. (2001). The literature of bibliometrics, scientometrics, and informetrics. Scientometrics, 52(2), 291-314. Retrieved from: https://doi.org/10.1023/A:1017919924342

[4] M Mani M Prakash, J Arumugam (2018) . Scholarly Research Output of Indian Institute of Management (IIMs) in India : Emerging Trends in Librarianship: Role of Libraries in Learning Environment (ISBN 9788192999906). 621-629.

[5] Mahapatra, M. (1985). On the validity of the theory of exponential growth of scientific literature. In Proceedings of the 15th IASLIC Conference. Bangalore, India, pp. 61-70.

[6] Meera, \& Sahu, S.K. (2014). Research output of University College of Medical Science, University of Delhi: A bibliometric study. COLLNET Journal of Scientometrics and Information Management. 8(2): 401-418.

[7] Moin, M., Mahmoudi, M., \& Rezaei, N. (2005). Scientific output of Iran at the threshold of the 21st century. Scientometrics, 62(2), 239- 248. Retrieved from https://doi.org/10.1007/s11192-005-0017

[8] Savanur, K., \& Konnur, P.V. (2012). Growth and impact of research output of Bangalore University, 1971-2010: A scientometric study. International Journal of Library and Information Science. 3(5): 71-80.

[9] Vasistha, S. (2011). Assessment of academic research output during 1996-2009: A study of PEC University of Technology, Chandigarh. DESIDOC Journal of Information Technology. 31(2): 136142.

[10] M. Tholkapiyan, A.Mohan, Vijayan.D.S , "A survey of recent studieson chlorophyll variation in Indian coastal waters", IOP Conf. Series: Materials Science and Engineering 993 (2020) 012041, doi:10.1088/1757-899X/993/1/012041. 